\title{
Analysis on the Project Curriculum Evaluation System Based on Vocational Ability
}

\author{
Yanrui Lei \\ School of Network Engineering \\ Hainan College of Software Technology \\ Qionghai, Hainan, China 571400
}

\author{
Laiquan Liu \\ Academic Affairs Office \\ Hainan College of Software Technology \\ Qionghai, Hainan, China 571400
}

\begin{abstract}
The curriculum reform of higher vocational colleges invariably focuses on training of high skills. The teaching reform of the project-based curriculum should not only break the original curriculum structure of the discipline and highlight the ability-preferred curriculum mode but also break the traditional evaluation mode and carry out the evaluation system suitable for the working process. By referring to foreign advanced vocational education curriculum modes, this paper discusses how to construct the evaluation system of the project curriculum based on vocational ability.
\end{abstract}

Keywords-higher vocational college; vocational ability; project-based; curriculum

\section{INTRODUCTION}

The Opinions of the Ministry of Education on Promoting the Innovation of the Higher Vocational Education Reform and Guiding the Scientific Development of the Vocational Education (J.Z.C [2011] No.12) explicitly points out that "the higher vocational education has the dual attributes of higher education and vocational education and should focus on training of high-end skill-oriented professional talents who will work at the first line of production, construction, service and management." The higher education should train satisfactory high-skilled talents and should manage to transform the knowledge to professional skills. The teaching of the projectbased curriculum takes work tasks and projects as carriers and aims at the completion of fixed and designed work projects and tasks, which will obviously promote the professional skills and abilities of students [1]. It needs to think about and solve the problem how to reform the existing curriculum evaluation method and escort the teaching of the project-based curriculum during the implementation of the project-based curriculum.

Chinese Library Classification No.: G710 Document Code: A

Project information: This paper is the partial research achievements of the Research and Practice of the Teaching Resource Database Construction of the Project-based Curriculum in Higher Vocational Colleges-Take < Installation, Configuration and Maintenance of Database> for Example (Project No. Hnjg2015-88), an education and teaching reform research project in Hainan Provincial higher education institutions.

This paper is the partial research achievements of the Research and Practice of the Development of the Project-based Curriculum-Take < Installation, Configuration and Maintenance of Database> for Example (Project No. Hr201508), an education and teaching reform research project of Hainan College of Software Technology

\section{CONNOTATION OF THE PROJECT-BASED CURRICULUM}

The project-based curriculum means that teachers take the project as the carrier, organize the learning content of students, cultivate the active learning ability of students and improve the ability of students to find and solve problems in accordance with the job requirements of enterprises, the ability of students and the current market demands.

\section{A. Process of the Project-Based Curriculum}

The development of the professional curriculum system of the higher vocational education should abide by the following three principles: firstly, it should emphasize that students can use all professional skills learned to solve problems; secondly, it should ensure that the learning process of students can make students personally experience the whole complete working process; thirdly, the learning content of students must be the skills required in the actual work [2].

Main problems that need to be considered in the project design include:

1) Project design patterns: The common project design includes the following there patterns:

Circulation type project design; in case the design of a course is to make students learn to complete three works tasks, the design of the project can start from the skill part which is easy to operate to the design of several projects in the more difficult skill part and students should repeatedly learn these three work tasks in each project The circulation type design pattern is relatively complex and some of work processes are even constantly repeated practices. However, owing to repeated practices in different projects, students will not feel very boring. With the constant increase of project difficulties, students can continually promote their skills accordingly.

Sectional type project design; The project is divided into several parts (small projects) in accordance with the boundary of work tasks; students complete all small projects step by step in accordance with the work sequence and finally finish the whole project. The core feature of the corresponding type project design should be respectively carried out around each work task. The project corresponds to work tasks and several projects can be designed around a work task. The number of projects designed targeted for a work task can depend on concrete demands. 
Corresponding type project design; projects correspond to the task and several projects can be designed around a work task as shown in the "Fig. 1". Certainly, the number of project designed around a work task should depend on the concrete demands [3].
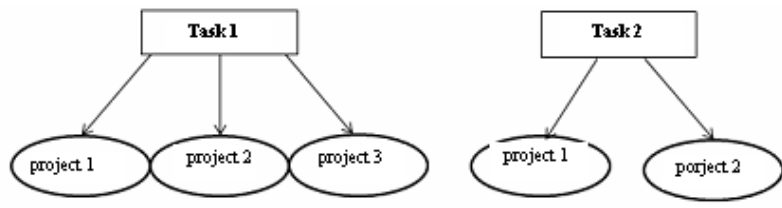

Fig. 1. Corresponding type project design pattern

2) Ability requirements in the project: The project-based curriculum needs to distribute the learning knowledge corresponding to each project in accordance with the actual work and the learning knowledge includes not only general ability but also professional skill [4]. No matter the projectbased curriculum selects circulation type project design, sectional type project design or corresponding type design, the project design should begin form the practical problems in the work. The project design has not only general ability requirements but also professional skill requirements as shown in the "Fig. 2".
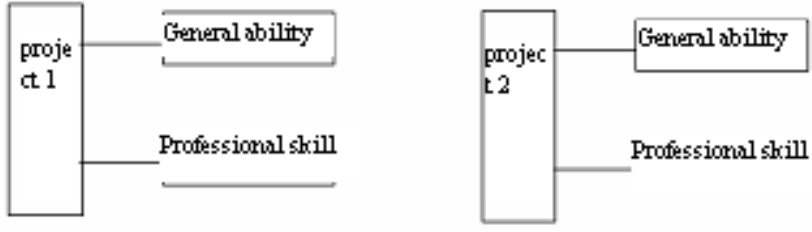

Fig. 2. Ability requirements in the project

\section{B. Characteristics of the Project-Based Curriculum}

The "project-based" curriculum highlights the studentsoriented leaning style and achieves the ability training objective. The learning content and style can be realized through dedicate design. The characteristics of the "projectbased" curriculum are presented in the following [5]:

(1) Form teachers-centered to students-centered;

(2) From teaching materials-centered to "project"-centered;

(3) From classroom-centered to actual work-centered.

\section{THE LOCAL AND INTERNATIONAL PROJECT-BASED CURRICULUM EVALUATION SYSTEM}

\section{A. German "Dual System" Vocational Education and Evaluation System}

At the school, students are these who attend classes; in the enterprise, they are apprentices who follow their masters to carry on practices; at the school, they mainly learn the theoretical knowledge and understand the working principle; in the enterprise, they mainly carry on practical operation and solve the problem that "how to operate well". Theoretical learning at the school and practical operation in enterprise coordinate each other [6].Tasks and class hours borne by the

enterprise and the school under the German "Dual System" vocational education mode are presented in the "Fig. 3".

Enterprise (70\%)

- $\quad$ Provide jobs for students

- Sign the paid vocational education contract

- Provide opportunities for students to carry on practices and practical trainings

- Organize examinations and evaluations

Fig. 3. German "Dual System" vocational education mode

Evaluation methods and content of the "Dual System" are presented in the "Table I":

TABLE I. Evaluation MEthods OF THE GERMAN "DuAl System" TO STUDENTS

\begin{tabular}{|c|c|c|}
\hline \multicolumn{2}{|c|}{ Evaluation Type } & $\begin{array}{c}\text { Responsible } \\
\text { Person/Department }\end{array}$ \\
\hline \multirow{2}{*}{$\begin{array}{l}\text { Usual } \\
\text { Examination }\end{array}$} & $\begin{array}{l}\text { Usual examination for } \\
\text { which the college is } \\
\text { responsible }\end{array}$ & Course teacher \\
\hline & $\begin{array}{l}\text { Usual examination for } \\
\text { which the enterprise is } \\
\text { responsible }\end{array}$ & Practical training teacher \\
\hline \multirow{2}{*}{$\begin{array}{l}\text { National } \\
\text { Examination }\end{array}$} & $\begin{array}{l}\text { National examination } \\
\text { for which the college is } \\
\text { responsible }\end{array}$ & $\begin{array}{l}\text { Uniformly organized by the } \\
\text { state }\end{array}$ \\
\hline & $\begin{array}{l}\text { National examination } \\
\text { for which the enterprise } \\
\text { is responsible }\end{array}$ & $\begin{array}{l}\text { National authorized agency } \\
\text { (such as the industry } \\
\text { association) }\end{array}$ \\
\hline $\begin{array}{l}\text { Graduation } \\
\text { Project }\end{array}$ & $\begin{array}{l}\text { The topic is designated } \\
\text { by the enterprise }\end{array}$ & $\begin{array}{l}\text { After the enterprise selects the } \\
\text { topic, it should be submitted to } \\
\text { the college examining } \\
\text { committee for approval. }\end{array}$ \\
\hline $\begin{array}{l}\text { Graduation } \\
\text { Thesis }\end{array}$ & $\begin{array}{l}\text { The graduation thesis } \\
\text { should be completed in } \\
\text { enterprise practices. }\end{array}$ & $\begin{array}{l}\text { The enterprise practical training } \\
\text { teacher acts as the first } \\
\text { instructor and the college } \\
\text { teacher acts as the second } \\
\text { instructor. }\end{array}$ \\
\hline
\end{tabular}

B. British BTEC Education Mode and Evaluation System

The British vocational education adopts the BTEC education mode. BTEC is the shortened form of the Business \& Technology Education Council, which is the major institution of the British national vocational education qualification training and curriculum development and is responsible for education of vocational colleges and development and the evaluation curriculum as well as teaching training. The BTEC education mode pays close attention to the development in both the academic aspect and the career aspect and emphasizes the students-oriented educational idea. Mutually formulated by industry and curriculum experts, the curriculum standards can maximally meet the actual work requirements; the evaluation runs through the whole learning process.

The BTEC education mode pays close attention to the synchronous development of general ability and professional skill of students. In order to obtain the BTEC curriculum certificate, students need to synchronously pass professional skill evaluation and general ability evaluation of the curriculum. The BTEC evaluation system is presented in the 
Fig.4. When designing assignments, besides basic professional skill objectives, teachers should determine several requirements of the general ability. Just take the general ability in the Fig. 4 for example, it should reflect the learning style, self-analysis mode, determination of development fields of students so as to adapt to their self-improvement demands [8]. However, the professional skill has a variety of evaluation modes such as investigation report, planning scheme, task analysis, installation, adjustment, presentation, mini test and so on. Teachers can optionally select one evaluation mode or make combination collocation as required. The BTEC evaluation system generally makes comprehensive evaluation through 3-5 assignments per unit and other auxiliary methods as well as daily activities in different forms.

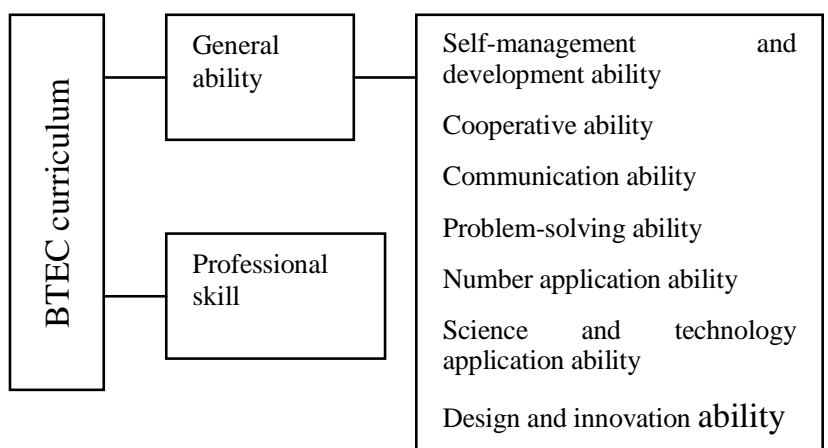

Fig. 4. BTEC evaluation system

\section{Australian TAFE Education Mode and Evaluation System}

The Australian TAFE is a comprehensive vocational technology education and training institution dominated by the industry and combined by government, industry and higher vocational colleges. The TAFE teaching mode emphasizes the subjective study initiative of students. Apart from the theoretical learning, the teaching process of the TAFE teaching mode also emphasizes training on practical working abilities of students so as to integrate theoretical teaching with practical teaching. In the Australian TAFE education mode, owing to the government requires the enterprise to carry on training to students through legislation and subsidize the enterprise that participates in the training at the same time, the enterprise has high enthusiasm to training. Generally speaking, the enterprise firstly puts forward the employee training demands and objectives. Then, the TAFE assigns the personnel to discuss with full-time teachers in the enterprise and formulate the training project, including the curriculum content, class hours, teaching materials, evaluation methods, place and so on. After the enterprise confirms, the TAFE implements the training project.

In the evaluation system of learning situations of students, the TAEE makes the minimum evaluation requirements on the training package curriculum, namely, teachers can adopt one method or several methods included in the 12 standard test methods to carry on curriculum evaluation. The standard test methods include observation, oral test, spot operation, a third party assessment, certificate, interview, self-evaluation, submission of case analysis report, production of workpiece, written test, video or other test methods. The evaluation result should meet validity, authority, sufficiency, uniformity and precedence [9].

\section{Present Situation of the Project-based Curriculum Evaluation System in China}

Learning from the vocational education experience at abroad, the curriculum reform of the vocational education in China is carrying out the project-based curriculum, but the curriculum evaluation system still emphasizes the theoretical and research-oriented talents. Lack of substantial content, the teaching reform of the project-based curriculum carries forward slowly. At present, the teaching of quite a few higher vocational colleges still attaches importance to the knowledge and neglect the practice; the curriculum reform carries forward slowly; the campus evaluation method still adopts knowledge examination and gives priority to written closed-book examination, the examination form of which is single; the evaluation content fails to attach importance to the completion of the project. Moreover, the basic theories included in more evaluation teaching materials are lack of comprehensive evaluation on the vocational ability and self-development of students.

\section{ANALYSIS OF THE VOCATIONAL ABILITY-ORIENTED PROJECT-BASED CURRICULUM EVALUATION SYSTEM}

Considering the main task of the higher vocational education is to train high-end skill-oriented professional talents who will work at the first line of production, construction, service and management, the project-based curriculum teaching reform carried out for training of high-skilled talents is required to perfect the evaluation system and still should follow the vocational ability-oriented principle. The projectbased curriculum evaluation system should be carried out from the following aspects:

\section{A. Evaluation on the Project Design}

Evaluation on the project design can start form "social demands and actual position demands" and can be judged from the following aspects:

- The design has clear objective;

- The project design is centered on students;

- The design is formulated by the industry or enterprise personnel;

- The design should clear and definite the general ability and professional skill that students should grasp in each project.

Besides the basic project design, the project-based curriculum evaluation system can refer to the three important teaching documents that complete the British BTEC requirements, including Teacher' Handbook, Students' Handbook and so on. The Teachers' Handbook regulates things that teachers should do in the teaching, for example, what theoretical knowledge that teachers should help students to grasp; teachers should pay attention to have a good knowledge of the learning dynamic of students and other things in the teaching process. The Students' Handbook is the 
necessary handbook for students use. In the Students' Handbook, students can read the situation of corresponding majors they learn, curriculum evaluation methods, curriculum teaching objectives and other contents [10].

\section{B. Evaluation on Teaching}

In the teaching process of the project-based curriculum, the evaluation on teaching of teachers can be carried out from the following aspects:

- Selection of the learning content should be reasonable and correct;

- The teaching process should meet the "vocational ability-oriented" requirements;

- Teachers should guide students to actively participate in classroom learning;

- Teachers should organize students to have a discussion;

- $\quad$ Selection of the teaching methods should cater for the student characteristics in the class as much as possible.

- Evaluation on students' ability

In the design process of the project curriculum, teachers should firstly think about how to evaluate the learning process and results of students. Evaluation on students can be carried out from two aspects, namely, general ability and professional skill [11]. The general ability mainly assesses abilities of students in actively solving problems, actively participating in discussion, carrying on communication or cooperation with others, innovation and other aspects. Evaluation content on the general ability can refer to the following aspects while the evaluation methods can be carried out with the combination of teacher evaluation and peer evaluation.

- $\quad$ Self-management and development ability;

- Cooperative ability'

- Communication ability;

- $\quad$ Social participation ability;

- $\quad$ Problem-solving ability;

- Number application ability;

- $\quad$ Science and technology application ability;

- Design and innovation ability;

Evaluation on the professional skill of students can give corresponding grade evaluation based on the completion situation of the project. Evaluation methods on the general skill can be diversified, such as observation, spot operation, peer evaluation, on-site defense, self-evaluation, written examination, video and other methods. The whole operation process can adopt one evaluation method or combination of different evaluation methods. The curriculums that do not have strong operability can adopt investigation report, planning report writing, analysis or comment on the past projects or other evaluation methods.

\section{CONCLUSION}

In the perfecting process of the project-based curriculum teaching system, higher vocational colleges should deeply comprehend the current "service and employment-oriented" development outline of the vocational education, put the improvement of profession ability and quality of students in the first place, carry out "vocational ability-oriented" project design, evaluate teaching of teachers and learning of students through scientific and feasible evaluation system so as to achieve the objective of imparting knowledge and educating people in the teaching of the project-based curriculum and provide further service for the education reform of higher educational schools.

\section{REFERENCES}

[1] Tan Zhuping. Development and Implementation of Practice-Oriented Project-Based Higher Vocational Education Curriculum. Discussion and Analysis on Higher Vocational Education, 2014, (6):95-96.

[2] Zhao Zhiqun. Discussion on Two Basic Cognition Issues Existed in the Development of the Project Curriculum from the Perspective of the Cultivation Project of Badly-needed Skilled Talents. Communication of Vocational Education, 2007(1):14-17.

[3] Xu Guoqing. Guide on the Curriculum Development of the Vocational Education Program, East China Normal University Press, July 2009.

[4] Cao Yang, Feng Qilin. Study on Design and Implementation of the Project-Based Curriculum Based on the Training of Professional Core Competencies of Higher Vocational College Students [J]. Vocational Education Research, 2014 (7):37-39.

[5] Sun Naiqian. Construction of the Vocational Activity-Orientated Project-Based Curriculum Evaluation System [D]. Shanghai: East China Normal University, 2009:16-18.

[6] Dai Shihong. Teaching Reform of Vocational Education Curriculum, Tsinghua University Press, June 2007.

[7] Wu Chunyan. Practical Study on the BTEC Teaching Mode in the Higher Vocational Teaching [J]. Journal of Hubei University of Science and Technology. 2015, (11):160-161.

[8] Wu Xiaoxia. Learn from the British BTEC Teaching Mode and Strengthen the Vocational Quality-Oriented Education [J]. Vocational Education Research, 2008, (4):137-138.

[9] Cui Yunkuo, Qin Dongmei. How to Establish and Perfect the Evaluation System of the School-Based Curriculum, Zhongguo Jiaoyu Bao, July 18, 2008, Edition 5 (The Institute of Curriculum \& Instruction East China Normal University).

[10] Zhang Bingjie. Comparative Study on Sino-Britain Vocational Education Curriculum Mode-Take the British BTEC Curriculum Mode For Example [J]. Vocational Education Research, 2015, (1):15-16 